\title{
"Cadê as nascentes?": A construção do diálogo e de política de gestão ambiental na comunidade do Douradinho, São Carlos - SP
}

"Where are the springs?": construction of dialogue and environmental management politics In
Douradinho community, São Carlos - SP

Alexandre da Silva Faustino - Universidade Federal de São Carlos - alexandre.mog@gmail.com

Raimunda Gomes Silva Soares - Universidade Federal de São Carlos - raigomessoares@yahoo.com.br

Mayara Herrmann Ruggiero - Universidade Federal de São Carlos - mayara.ruggiero@hotmail.com

Nícolas Guerra Rodrigues Tão - Universidade Federal de São Carlos - nicolas.tao@hotmail.com

Érica Pugliesi - Universidade Federal de São Carlos - epugliesi@gmail.com

Juliano Costa Gonçalves - Universidade Federal de São Carlos - juliano@ufscar.br

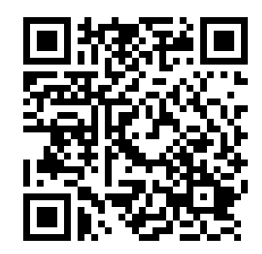

\begin{abstract}
Resumo: O presente trabalho tem o objetivo de construir um diálogo entre o conhecimento científico e o conhecimento local em relação aos aspectos ambientais dos bairros Parque Douradinho, Jardim Tangará e São Rafael, situados no município de São Carlos-SP. Para isso, foram realizadas, na região, oficinas abertas ao público em geral, aplicando-se a metodologia de grupos focais. Como resultado final desses encontros, foi elaborado um documento, o plano de ação, produto do diálogo entre os saberes científicos e locais, contendo as necessidades da população, com a aprovação dos participantes das reuniões. Por fim, os próprios participantes, por meio das reuniões, puderam realmente contribuir e colocar em prática suas ideias e atitudes no que diz respeito à sua relação com o meio ambiente, as quais foram complementadas pelas apresentações teóricas realizadas pela equipe do projeto. A continuidade e o fortalecimento das ações propostas são possibilitados pelas parcerias estabelecidas, devido à mobilização social iniciada, e pelos meios de comunicação e fundamentação teórica repassada e disponibilizada à comunidade.
\end{abstract}

Palavras-chave: socioambiental, mobilização social, grupo focal, conhecimento local.

\begin{abstract}
This article intends to build a dialogue between scientific knowledge and local knowledge related to environmental features of the neighborhoods of Parque Douradinho, Jardim Tangará and São Rafael located in São Carlos city, SP. For this, there were made open workshops to general public in that region, applying the methodology of focus groups. The final result of these meetings was a document, the action plan, based on the dialogue between scientific and local knowledge, containing the population's needs, with the approval of the participants of the meetings. Finally, the participants could really contribute and put into practice by themselves their ideas and attitudes about their relationship with environment through the meetings, which were complemented by theoretical presentations made by the project team. The permanence and strengthening of the proposed actions are able because the partnerships initiated due social mobilization and because the media and theoretical bases available to the community.
\end{abstract}

Keywords: socio-environmental, social mobilization, focus groups, local knowledge.

A deterioração da qualidade ambiental nas áreas urbanas é multidimensional e está ligada a variáveis sociais, econômicas e políticas, além, é claro, da própria concepção de mundo sobre a importância dos aspectos ambientais. Os territórios urbanos possuem diferentes conformações, devido às diferentes correlações de forças entre processos econômicos, sociais, políticos e ambientais, dos qual são frutos e que continuam a operar no momento presente.

O processo de desenvolvimento de territórios urbanos pode ser diferenciado em dois tipos, que são: a cidade formal e a cidade informal. De acordo com TUCCI (2005), cidade formal compreende áreas de médio e alto valor econômico que apresentam planejamento urbano, ao passo que na cidade informal, considerada de baixo valor 
econômico, são realizadas somente análises de tendências da ocupação.

Ainda assim, mesmo com planejamento urbano, a cidade formal pode apresentar (e, em grande parte dos casos, apresenta) problemas com sua infraestrutura e ainda gerar impactos ambientais, definidos, segundo a resolução do CONAMA (Conselho Nacional do Meio Ambiente) $n^{\circ} 01$, de 23/01/1986, como "qualquer intervenção antrópica que afete diretamente ou indiretamente as propriedades físicas, químicas ou biológicas do meio". Isso pode ser evidenciado nos processos de erosão, assoreamento, contaminação das águas, do solo e do ar, além da alteração do ciclo hidrológico.

Outro aspecto da urbanização a ser considerado são os detritos carreados com maior intensidade, devido à remoção da vegetação natural das áreas ocupadas, contribuindo assim para o assoreamento dos corpos hídricos em geral (TUCCl, 2005). Além dos detritos, destacam-se também os resíduos sólidos, que, quando mal gerenciados (grande maioria das situações), interagem com o ciclo hidrológico, podendo ser carregados pelo escoamento superficial para o sistema, causando aumento da sedimentação e poluição. Dentre os corpos hídricos afetados, estão aqueles em locais ambientalmente mais sensíveis, tais como as nascentes, que apresentam grande importância para a dinâmica fluvial, pois marcam a passagem da água subterrânea para a superficial pela infiltração. Também é de responsabilidade das nascentes alimentar constantemente os aquíferos, a manutenção dos fluxos dos rios e córregos, mesmo em períodos secos, já que nesses casos a água da chuva se torna efêmera (FELIPPE e JUNIOR, 2009).

Nesse sentido, "(...) a urbanização, ao modificar de maneira tão intensa as relações entre o meio natural e a cidade, gera entre ambos, completa união e solidariedade indestrutível, não permitindo mais a adoção de ações isoladas" (ALMEIDA, 2002). Considera-se, portanto, que uma vez que o processo de urbanização já se encontra estabelecido, a comunidade e o ambiente natural passam a interagir fortemente e várias modificações do espaço podem resultar dessa interação.

Dessa forma, um importante ponto inicial é identificar a percepção ambiental da comunidade a qual é definida por FERRARA (1999) como: "informação na medida em que a informação gera informação: usos e hábitos são signos do lugar informado que só se revela na medida em que é submetido a uma operação que expõe a sua linguagem".

A concepção adotada de percepção ambiental por este projeto segue a indicação de MELAZO, G. C. (2005), que a utiliza em um sentido mais amplo como sendo uma "tomada de consciência do ambiente pelo homem". O autor ressalta ainda que tal processo é condição primária para a ocorrência da sensibilização, da conscientização e do conhecimento, no sentido de "despertar na sociedade ações positivas que sensibilizem os indivíduos e educandos da importância de se preservar o meio ambiente". Essa necessidade é ainda mais evidente quando se trata de reduzir impactos ambientais e contribuir para uma melhor qualidade de vida em comunidades urbanas.

O que se pretende é construir uma interface entre os conhecimentos científicos sobre os impactos negativos da urbanização, bem como sobre as potencialidades região, considerando-se a visão que os moradores têm do lugar, e a partir disso levá-los à reflexão sobre suas próprias atitudes e também sobre o bairro que se deseja e quais ações podem ser feitas neste sentido. Essa abordagem baseia-se na concepção de uma educação ambiental crítica e emancipatória, descrita por GUIMARÃES (2005) como uma educação comprometida com a transformação da realidade rumo à sustentabilidade socioambiental, que considera o ambiente educativo um movimento aderido à realidade com a qual se contextualiza, fato que permite que a transformação da realidade socioambiental se dê a partir da reflexão-ação, potencializando, dessa forma, a ação cidadã de sujeitos individuais e coletivos.

É ainda importante por possibilitar a construção de um "diálogo entre os saberes", conceito definido por (FLORIANI, 2007) como:

(...) possibilidade de se estabelecer intercâmbios entre diversas áreas de conhecimento humano, seja entre aqueles reconhecidos e legitimados pelas instituições produtoras e difusoras do conhecimento científico, como entre outros conhecimentos considerados não-científicos (saberes culturalmente arraigados).

A partir da troca de informações entre os conhecimentos existentes, é provável que se observe um movimento nesses intercâmbios, tanto no interior do sistema científico, quanto entre os conhecimentos "populares" (FLORIANI, 2007).

Parte-se do princípio de que o conhecimento científico sozinho dissociado de um contexto e dos aspectos sociais e culturais a ele relacionados torna-se obsoleto em seus objetivos, uma vez que deixa de cumprir seu papel social. Como afirma LEFF (1998) apud CARVALHO e GRUM (2005), "desde uma perspectiva compreensiva o saber ambiental é justamente aquele que transborda o campo das ciências ambientais".

A ação torna-se um processo educativo e emancipatório na medida em que, ao identificar a percepção ambiental, favorece a tomada de consciência tanto dos problemas ambientais quanto da necessidade de ações no sentido de sua resolução. Dessa forma, a construção de um diálogo 
de saberes torna-se um espaço educativo quando permite tanto a disponibilização do conhecimento científico que embase soluções de problemas quanto a possibilidade de essas soluções partirem das próprias pessoas que os vivenciam,_fato que potencializa o sucesso e a continuidade desse processo, respaldando-o dentro de seu contexto.

\section{Objetivo Geral}

Construir o diálogo entre os conhecimentos científicos e o conhecimento local em relação às questões ambientais dos bairros Parque Douradinho, Jardim Tangará e São Rafael.

\section{Objetivos Específicos}

- Disponibilizar informações técnicas básicas sobre a região que subsidiem ações de planificação e de prioridade de atividades inerentes à melhoria das condições ambientais do bairro.

- Fornecer subsídios por meio de canais virtuais de integração e divulgação de informações que possibilitem o incentivo a atitudes de respeito em relação ao ambiente natural pelos participantes das atividades.

- Permitir um diálogo entre os pesquisadores e a população para discutir as questões ambientais da região.

- Definir coletivamente ações ambientais prioritárias.

- Contribuir para a integração social entre os moradores da região no sentido da sustentabilidade da área de estudo.

- Criar um espaço virtual de integração comunitária que possibilite a divulgação de informações de interesse coletivo, planejamento de atividades, sugestões e reclamações.

\section{Caracterização da COMUnidAde dO DOURADINHO}

Este trabalho compõe mais uma etapa do Projeto "Cadê as Nascentes?", que foi criado para permitir um diálogo entre conhecimentos científicos e conhecimentos locais sobre as questões ambientais da comunidade do Douradinho (que abrange os bairros Douradinho, São Rafael e Jardim
Tangará), em busca de sensibilização e conservação ambiental nessa região. A área de atuação do projeto insere-se na bacia hidrográfica do Rio Monjolinho (Figura 1), sendo formada por uma parte do núcleo urbano da cidade de São Carlos - SP, composto pelos bairros: Parque Residencial Douradinho, São Rafael e Jardim Tangará, que abrangem um total de 5.194 pessoas (Figura 2).

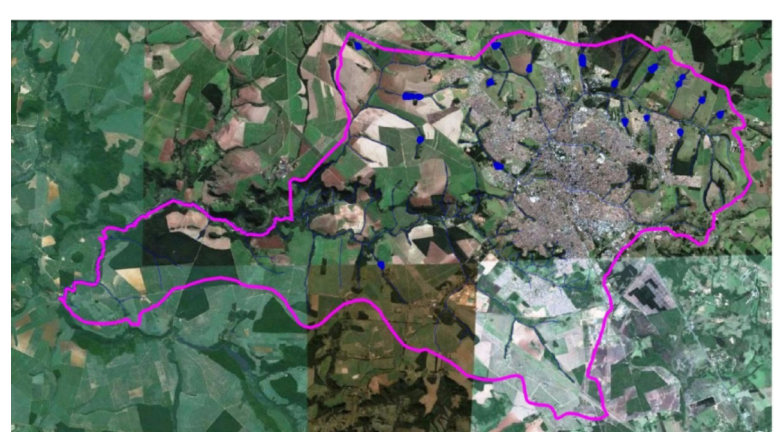

Figura 1 - Bacia Hidrográfica do Córrego do Monjolinho, em escala de aproximadamente 1:100.000.

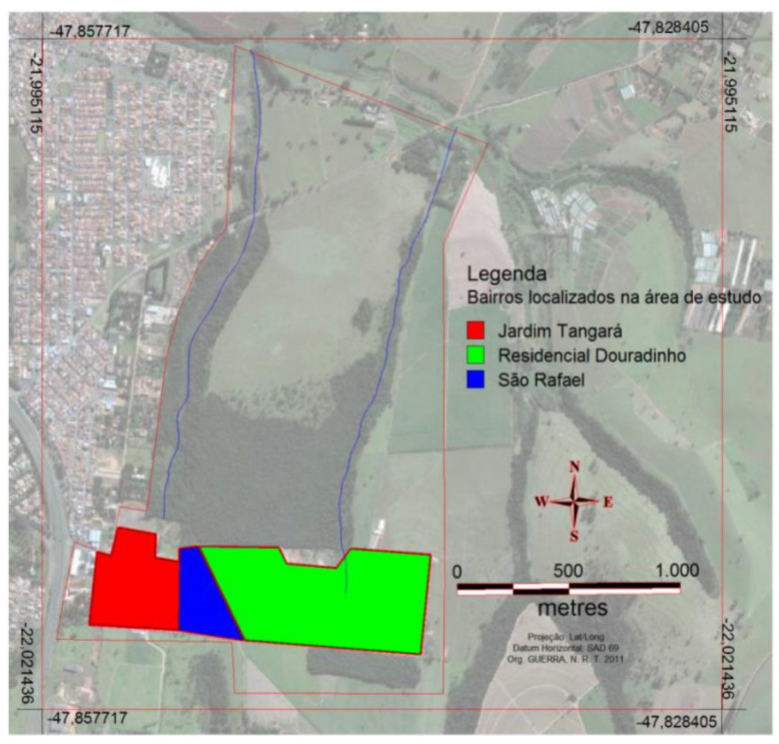

Figura 2 - Delimitação dos bairros na área de estudo.

A região teve seu processo de ocupação iniciado na década de 1970, com o bairro Jardim Tangará. O bairro Parque Residencial Douradinho foi inicialmente loteado em 2001 pelas empresas Araguaia Construtora Brasileira de Rodovias S/A e Douradinho Empreendimentos Imobiliários LTDA, com financiamento da Caixa Econômica Federal, possuindo 1297 lotes (Figura 3 - Fonte: Google Earth , 2011) (SOARES, 2008). Nesse processo foi possível observar que inicialmente houve uma preocupação apenas com 
a infraestrutura n ecessária para a instalação do bairro, não existindo medidas de proteção em relação às áreas de mananciais presentes em seu entorno. Com isso tais núcleos urbanos acabaram por invadir as áreas de preservação permanente, que se encontram hoje, por força das circunstâncias, em muitos trechos ausentes ou degradadas em decorrência do processo de urbanização.

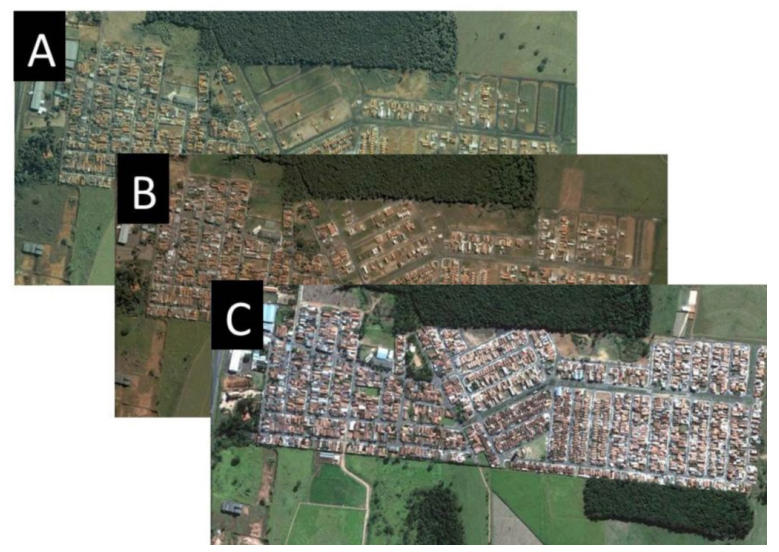

Figura 3 - Urbanização na Região do Parque Residencial Douradinho,
2004 (A), 2005 (B) e 2011 (C), (Google Earth, 2011).

FAUSTINO et al. (2012), ao realizarem uma caracterização da região (Gráfico 1), mostraram que o produto da urbanização ocorrido foi a conformação de uma área predominantemente residencial (70\% do uso do solo), envolta por áreas destinadas majoritariamente ao uso para agricultura e pecuária, além da presença de um significativo remanescente de vegetação consolidada que, estando no limite da área dos bairros, interage diretamente com eles.

Com esse cenário, a importância ambiental da região é salientada por meio de várias disposições legais do município, dentre as quais está o Plano Diretor instituído pela lei $n^{\circ}$ 13.691/05, que estabelece, entre outras diretrizes, atenção especial à preservação e recuperação ambiental. A área compreendida pelo remanescente florestal é classificada como "Zona 5A de Proteção e Ocupação Restrita" (Art $23, \S 1$, inciso II), caracterizada como área de preservação do manancial de abastecimento público, para a qual estão estabelecidas normas específicas de uso e ocupação, como o controle do adensamento urbano, monitoramento das atividades rurais e restrições no parcelamento e uso do solo, com o objetivo de "Promover a proteção e a recuperação

Gráfico 1 - Representação qualitativa das porcentagens de território ocupado por cada atividade de uso do solo na região em 2011.

\section{Porcentagem de Uso e Ocupação}

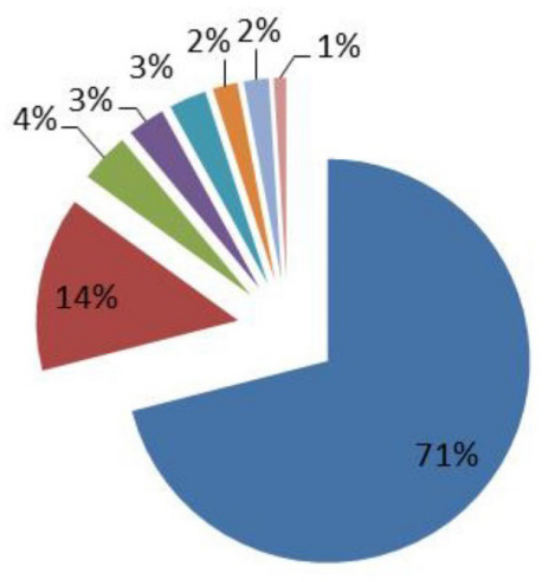

áreas Residenciais

- Terrenos Baldios

áreas Verdes Urbanas

- Comércio

Escolas

- Ong

- Pequenos Cultivos Urbanos

- Construções Abandonadas

Fonte: FAUSTINO, et al. 2012. 
da qualidade e quantidade de águas superficiais que compõem os mananciais de abastecimento público" (Art. 45 inciso IV). A mesma região também é atribuída como "Área de Especial Interesse Ambiental", onde é prioritária a preservação, recuperação e reflorestamento.

Como o núcleo urbano localiza-se em uma região de cabeceira de diversos afluentes dos corpos hídricos do município, a área urbana em si é caracterizada, segundo o Plano Diretor, como Zona de Recuperação e Ocupação Controlada 3B (Art. 22, $\S 1^{\circ}$, inciso III), o que estabelece algumas diretrizes para o uso e ocupação da área, dentre elas "regulamentar e disciplinar o uso e a ocupação do solo para proteção do manancial superficial" (Art. 35., inciso II).

A importância ambiental da região também é destacada por sua classificação na Lei Municipal 13.944/06 como uma APREM/SC (Área de Proteção e Recuperação dos Mananciais do Município), que visa buscar a proteção e recuperação das áreas de manancial, "principalmente através da recomposição da vegetação ciliar, ripária ou de galeria" (Art. 4, inciso I). Isso se dá em função da existência de duas nascentes de dois afluentes do Rio Monjolinho: o Córrego São Rafael e Córrego Douradinho, inseridos em um dos maiores fragmentos florestais remanescentes dessa bacia.

As nascentes de ambos os córregos encontram-se no limiar da área urbana, e nesses pontos é que são representados todos os efeitos adversos para o ambiente, decorrentes das atividades que acontecem nos bairros. Outros fatores físicos contribuem para acentuar ainda mais a fragilidade das áreas de nascentes, como a presença de solo predominantemente arenoso e concentração das áreas mais declivosas da região nesses locais; e como recebem todo o escoamento no núcleo urbano a montante, apresentam um alto potencial para ocorrência de processos erosivos (FAUSTINO, et al. 2012).

\section{A IMPORTÂNCIA AMBIENTAL DA REGIÃO}

Além da importância ambiental da região supracitada, salienta-se que a mata que se encontra perimetralmente aos bairros é um dos maiores fragmentos florestais em contato com a área urbana na Bacia do Monjolinho.

É fundamental, de um ponto de vista conservacionista, informar a população a respeito dos impactos ambientais que o patrimônio natural vem sofrendo pela ação antrópica originada muitas vezes da própria população como reflexo no mau planejamento urbano da região. Afinal, esse patrimônio natural pertence a todos os cidadãos e, principalmente, à população local, já que parte da mata está incluída no "Sistema de Lazer" do loteamento.
Esses impactos causados, resultantes em grande parte do planejamento do poder público, têm reflexos diretos sobre a população, sendo de extrema relevância que se informe sobre tais fatos e busquem-se soluções conjuntas que não levem em conta somente os saberes científicos, tendo em vista que, uma vez que o processo de urbanização já se encontra estabelecido, a comunidade e o ambiente natural passam a interagir fortemente e várias modificações do espaço podem resultar dessa interação. Com isso, partindose do consenso sobre a iminente necessidade de conservação das nascentes, é preciso que qualquer ação de conservação seja construída, imprescindivelmente com a participação da comunidade, de forma a conciliar as necessidades locais, tanto no aspecto social quanto ambiental.

\section{Metodologia}

A realização deste trabalho foi estruturada por meio de oficinas com os moradores dos bairros, conduzidas por meio da metodologia do grupo focal apresentada por GOMES e BARBOSA (1999), que pressupõe a realização de discussões em um grupo reduzido de pessoas (cerca de 12 membros) para obter informações qualitativas sobre determinado assunto, com pelo menos um participante responsável pela condução dos diálogos (moderador) e um responsável pelos registros (relator), essenciais para a análise dos resultados. No grupo focal, a condução da discussão deve estar baseada em tópicos pré-definidos e é mais bem aproveitada com uma duração média de 2 horas.

A proposta inicial foi que tais oficinas fossem aplicadas pontualmente em diferentes locais, com diferentes públicos, devido à dificuldade de se fazer um trabalho contínuo com os mesmos participantes por mais de uma oficina.

As oficinas seriam então aplicadas em igrejas, na ONG do bairro, ou em outros locais onde as pessoas já estivessem e a equipe do projeto tivesse que se deslocar para o local, e não os moradores, o que facilitaria atingir o público. Porém, decidiu-se que a primeira reunião seria feita de forma aberta no quiosque da Praça A. Campos, no bairro Parque Douradinho, no sábado, dia 26/10/2013, às $17 \mathrm{~h} 30$, sendo o dia da semana e o horário definidos estrategicamente para que houvesse maior adesão possível, já que a maioria dos moradores poderiam estar disponíveis. A decisão pela reunião aberta tinha o intuito de testar se haveria adesão dos moradores, antes de se aplicar a estratégia de estabelecer parcerias com igrejas e outros locais, pois a reunião aberta permite que o grupo seja composto com uma diversidade maior de pessoas, apesar da quantidade de presentes variável, tendo em vista que 
o deslocamento para o local depende do indivíduo e não da equipe do trabalho. O local foi escolhido por ser parte integrante do próprio sistema de lazer dos bairros e tendo em vista a relação que o uso desse espaço tem com o tema abordado na reunião. Além disso, o espaço era utilizado para eventos dos moradores e para a reunião da antiga associação, sendo que o ambiente encontra-se atualmente subutilizado e extremamente sujo devido a uma infestação de pombos. O espaço também é acessível e conhecido na região, além de ser coberto, o que evitaria problemas em caso de chuva.

Foi feito, então, um trabalho de divulgação por meio de cartazes pelo bairro, fixados em comércios, escolas, pontos de ônibus e também por meio de convites verbais para pessoas que estivessem nesses locais. Os comerciantes que aceitaram receber os cartazes foram orientados a convidar as pessoas que frequentam o comércio. Também foi feito convite por e-mail para algumas lideranças do bairro, como um representante do sindicato dos metalúrgicos que é morador da região, participantes da associação de moradores desativada, entre outros. Outro importante meio de comunicação foi o site do projeto (www.cadeasnascentes.wix.com/douradinho-saorafael), estruturado com todas as informações que seriam passadas no encontro, e com banners contendo as informações de local, data e horário da reunião, o Facebook do projeto, que foi amplamente divulgado, e o canal do Youtube, com alguns vídeos da região.

Devido aos resultados da reunião aberta ao público, optou-se por um segundo encontro também aberto com os mesmos moradores, sendo abandonado o formato de parcerias com Igrejas e ONG's. Esse encontro foi realizado no dia 09/11/2013, no mesmo local e horário.

Como reforço de divulgação para esse segundo encontro, foi gravado um áudio, em parceria com a ONG Casa Fora do Eixo, em que eram noticiados o local do encontro, o assunto principal e o horário. Esse áudio foi transmitido em todas as ruas da região em um carro de som, durante a manhã do dia anterior (08/11/2013) e no próprio dia do evento, sendo que o carro de som foi patrocinado por meio de uma parceria estabelecida com um dos integrantes do Sindicado dos Metalúrgicos, morador da região. Foram distribuídas filipetas de papel com informações da reunião e o site do projeto para todos os alunos da EMEB Antônio Stella Moruzzi, escola primária da prefeitura localizada no bairro Jardim Tangará, com aproximadamente 611 alunos, solicitando-se que estes entregassem para seus pais. Esse material de apoio foi fornecido pela parceria com o Escritório de Advocacia SILVERA \& SOARES. Em trabalho anterior realizado na ONG ASPE, também foi divulgado o site do Projeto.
A reunião foi divulgada na Rádio UFSCar, no programa "Independência ou Marte", transmitido na segunda-feira (04/11/2013), às 22h.

A primeira oficina foi, então, estruturada em etapas, todas sendo realizadas dentro de duas horas. Na primeira etapa foi realizado um diagnóstico dos moradores presentes, apresentando-se um mapa da região, contendo seus pontos principais, como praças e ruas, que serviriam como referência. Apresentado o mapa, foi perguntado aos participantes quais problemas e potencialidades existentes na região eles poderiam indicar. Os moradores, então, realizaram seu próprio diagnóstico do bairro em aproximadamente 40 minutos. Esse diagnóstico foi simultaneamente escrito nos slides na própria apresentação, para que os moradores verificassem se o que estava sendo ditado estava corretamente registrado e para que, ao final do processo, pudessem visualizar todos os problemas e potencialidades que indicaram. A equipe do projeto teve pouca ou nenhuma participação nessa etapa, sendo seu papel apenas o de incitar a discussão, seguindo a estrutura de um grupo focal, em que alguns membros da equipe assumem o papel de moderadores, buscando ampliar o diálogo ao máximo e explorar os temas que são levantados, evitar que indivíduos do grupo dominem a discussão e incentivar que todos expressem suas opiniões, sendo, ainda, papel dos moderadores manter a imparcialidade. $\mathrm{O}$ incentivo à discussão era feito por meio de perguntas dirigidas aos moradores a fim de que complementassem suas argumentações, espacializassem seus comentários no mapa e expressassem suas opiniões, como "Onde está localizado?", "O que você acha sobre isso?", "O que poderia ser considerado uma potencialidade?", "Existem problemas na região? (Se respondessem sim, como eles ocorrem? Falem sobre eles)", entre outras perguntas motivadoras.

Outro integrante do grupo, responsável pelas anotações, manteve-se registrando os dados e reações relevantes, não interferindo no diálogo ou no papel dos moderadores. Além desse recurso, todo o processo foi gravado integralmente com câmera de vídeo para posterior análise e consulta. Os participantes foram informados anteriormente que membros da equipe estariam exercendo tais funções.

Quando o moderador notou que a discussão foi explorada ao máximo, foi feita uma observação de todos os aspectos citados e perguntado se algum presente possuía alguma informação adicional ou correção dos problemas e potencialidades listados.

Após essa fase, a equipe de trabalho apresentou, então, uma caracterização geral da área, citando todos os trabalhos e informações coletadas na região, de aspectos físicos, biológicos, sociais, geográficos, entre outros, assim 
como o conhecimento científico produzido, destacando problemas e potencialidades na visão teórica. Durante todo o processo, existiu o cuidado para que a visão apresentada pela equipe não sobrepusesse os saberes regionais e o diagnóstico apresentado pela população. Desse modo, buscou sempre citar aspectos coincidentes entre os dois diagnósticos e enfatizou fatos citados pela população que eram de desconhecimento da equipe do projeto, visando a uma abordagem não excludente e que não indicasse qualquer desqualificação da informação transmitida pela população. Após e durante esse processo, os participantes foram consultados a respeito de dúvidas, sugestões e concordância ou discordância de se considerarem tais aspectos apresentados como problemas e potencialidades.

Apresentados ambos os diagnósticos, a população foi questionada no que diz respeito a soluções, o que realizar para lidar com os problemas do bairro, como melhorar a região para aumentar suas potencialidades, sempre pensando nos problemas apontados pelas pessoas e pela equipe. A proposta era reunir todos os aspectos em um conteúdo único. A estrutura de exploração da discussão foi a mesma apresentada na primeira fase de diagnóstico, sendo feita em formato de grupo focal.

Foram apresentadas, então, pela equipe do projeto algumas soluções técnicas para problemas mais estruturais, buscando mostrar a visão científica sobre as soluções, seguindo a mesma estrutura da apresentação anterior.

Por fim, apresentadas e relacionadas ambas as opiniões, estabeleceu-se a prioridade das ações, momento em que novamente todos tinham o espaço para melhorar as soluções, incluir ou excluir problemas, sendo que o resumo das informações coletadas no encontro foi apresentado em um slide, permitindo, assim, que todos opinassem e visualizassem o que havia sido produzido até então. Na tabela projetada, foi estabelecida a prioridade das ações, buscando elaborar um plano de ações.

Nesse momento, foi sugerida pelos próprios moradores uma nova reunião, para discutir melhor as ideias do plano de ação e suas prioridades, buscando estabelecer profundidade na discussão.

O segundo encontro foi marcado, tendo sido realizada uma divulgação mais intensa, como já citado. Devido ao comparecimento de novas pessoas, a estrutura do segundo encontro, que seria somente para as prioridades, acabou por repetir os tópicos da reunião anterior, de forma mais resumida, permitindo um maior espaço para a discussão das prioridades e do plano de ação ao final. O Documento foi então compilado pelos moradores juntamente com a equipe do projeto.

Em ambas as reuniões, foi solicitado aos moradores que assinassem uma lista de e-mails e presença, para manter o contato, além de um termo de permissão de divulgação da imagem. O site também foi divulgado, como mecanismo de contato e continuidade do projeto, assim como o Facebook. Elaborou-se um fluxograma, em que foram esquematizadas as principais etapas do projeto (Figura 4 ).

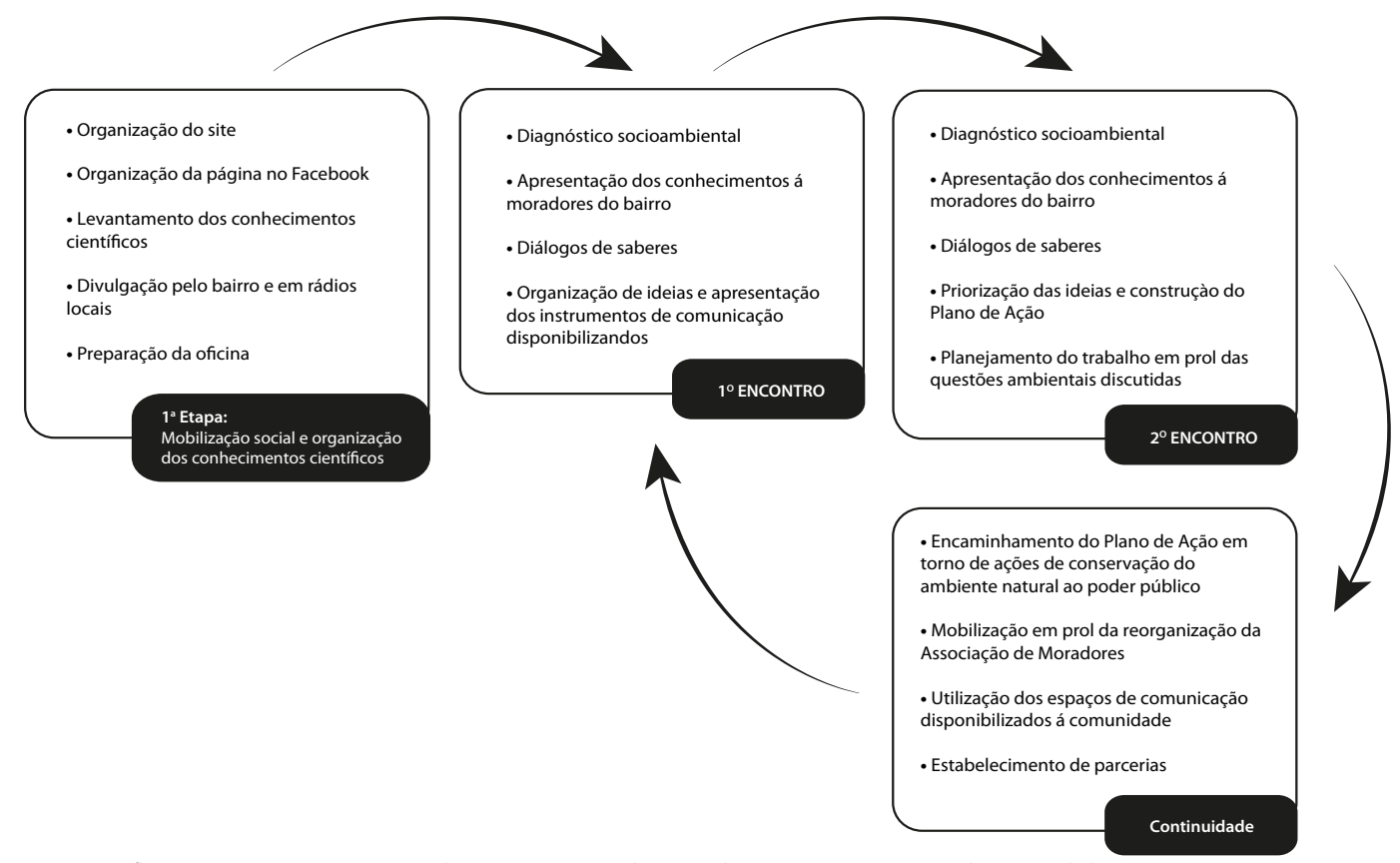

Figura 4 - O fluxograma apresenta um resumo das principais etapas do projeto bem como as perspectivas de continuidade. 


\section{Resultados E DISCUSSÃO}

\section{Primeiro encontro}

No primeiro encontro, realizado no dia 26 de outubro de 2013, compareceram 10 moradores ao todo, os quais começaram a chegar ao local meia hora após o horário agendado. Como eles chegavam aos poucos, foi necessário prorrogar o início das atividades, o que consumiu parte do tempo previsto para o encontro. A reunião iniciou-se com a apresentação dos autores, (Figura 5) aos moradores do bairro, seguida por uma explanação rápida do intuito da reunião. Em seguida, deu-se início ao levantamento do conjunto de problemas e potencialidades existentes na região, partindo apenas da noção apresentada pelos moradores ali presentes.
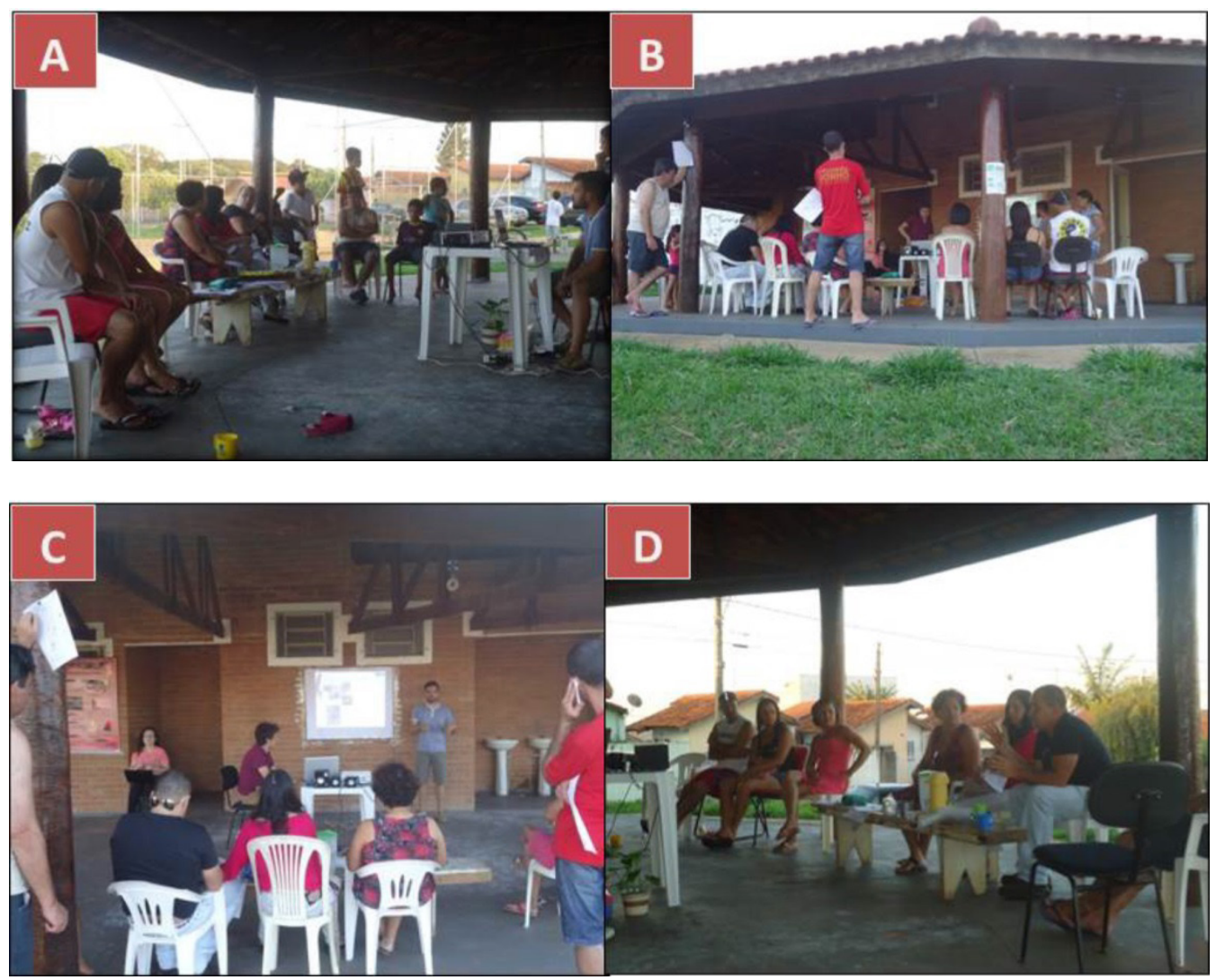

Figura 5 - Primeiro encontro realizado com os moradores, na sequência: A (Ouvindo a comunidade) B e C (Apresentação dos conhecimentos científicos), D (Discussão e unificação das informações).

Foram obtidas respostas tanto para problemas pontuais que puderam ser especializados com o auxílio do mapa quanto para problemas gerais que se repetem em vários locais. As informações levantadas junto à população estão sumarizadas no Apêndice, organizadas segundo os seguintes pontos: Coletividade, Gestão dos resíduos, Equipamentos urbanos, Controle de zoonoses, Planejamento e Reivindicações da população.

Dentre os pontos levantados, estava a falta de conservação de alguns espaços públicos que são muito utilizados pela população, como a própria praça onde foi realizado o encontro, a qual fica deteriorada pela presença de pombos, além de não passar por manutenção de equipamentos e infraestrutura, situações que acabam produzindo riscos aos frequentadores. Os moradores apontam para problemas envolvidos com podas de árvores, que não estão sendo realizadas adequadamente, e reclamam da escolha de espécies arbóreas que, no futuro, podem causar problemas, como: quebra de calçadas, risco de quedas e curto tempo de vida útil, como o chorão (Salix babylonica), espécie que está sendo distribuída amplamente pela prefeitura e plantada em canteiros e praças.

A questão do controle de zoonoses também os preocupa e remete a cães e gatos de rua, que podem ser violentos 
e atacar a população, bem como a animais perigosos e peçonhentos, que chegam às casas com frequência em decorrência da proximidade com os fragmentos de mata e também pela alta incidência de terrenos desocupados e mal conservados. Os moradores ainda citaram que existem aspectos de inadequações do planejamento do bairro que geram conflitos, como a existência de uma única entrada e uma única saída para a região, o que contribui com seu isolamento. Na concepção de alguns presentes, esse também era um aspecto negativo.

Porém, os problemas mais citados e mais evidentes foram aqueles relacionados à gestão dos resíduos na região. A ausência de uma coleta seletiva formalizada e eficiente surgiu como um problema, pois, embora os moradores se mostrassem dispostos e interessados em separar os resíduos recicláveis, não dispunham dos meios para proceder com a destinação adequada, e isso era ainda mais prejudicado pelas práticas dos catadores da coleta informal, que, de acordo com o relato dos moradores, acabam espalhando os resíduos pelas calçadas quando selecionam o que Ihes é de interesse, e isso faz com que os moradores não contribuam com os catadores informais.) A questão mais discutida relacionada aos resíduos foi a existência do despejo clandestino de resíduos em diversos pontos dos bairros. Esses resíduos ficam acumulados, deteriorando a paisagem e oferecendo riscos à população, pela possível instalação de vetores de doenças. Essa situação é verificada especialmente nos terrenos baldios que não possuem qualquer tipo de uso e nas regiões limítrofes do bairro. Vale ressaltar que o resíduo mais problemático na região é o da construção civil (RCC), dada a recente ocupação da área. Como existem muitas obras sendo realizadas, a geração desse tipo de resíduo é expressiva. De maneira geral ainda foi citada a falta de conscientização da população para os problemas do bairro e a falta de mobilização.

Pela resposta obtida, fica claro que a população destaca como problema aquilo que surge para si por meio de seus hábitos. Isso fica evidente para todos. Os resíduos foram amplamente citados, uma vez que é um problema muito visível e produz diversas consequências que afetam a população. Não surgiram questões ligadas mais diretamente aos problemas ambientais das nascentes e da mata, pois existe certo distanciamento da população em relação ao ambiente de entorno, que aumenta ainda mais pela ausência de informações sobre esses locais.

Apesar disso, esse ambiente de entorno foi mencionado como uma das potencialidades. A população destacou o potencial que a região possui na realização de atividades de turismo ecológico e atividades que envolvam um maior contato com a natureza. Fica claro que há a percepção da existência desse ambiente natural e que este pode trazer benefícios à população, mas essa relação ainda não existe, o que distancia os moradores dos problemas ambientais ali encontrados, sendo que muitos deles resultam das próprias atitudes da população. Quando esse contato é estimulado, estabelece-se uma relação positiva, o que foi verificado com a colocação da existência dos canteiros centrais nas vias bem cuidados como uma potencialidade, pois são espaços agradáveis para os moradores. Esse potencial, o de se explorar a região como um local de lazer, ampliando os espaços públicos e promovendo sua conservação, é o que mais foi levantado durante esse ponto da discussão.

O momento seguinte envolveu a exposição das informações que o grupo possuía sobre a região e sobre os problemas ambientais existentes. Os participantes mantiveram-se atentos por todo momento, e, pela concepção aberta e participativa da discussão, houve contribuições ao longo da exposição, bem como se constatou a necessidade de maior aprofundamento e explicações de conceitos que eram muito distantes do conhecimento popular, como os dissipadores de energia. Ao mesmo tempo, os participantes deram contribuições às propostas apresentadas pelo grupo, pois, quando foi comentada a possibilidade de se aplicarem multas para proprietários que tenham terrenos baldios em más condições, com acúmulo de resíduos, propuseram que houvesse um mecanismo similar que punisse a prefeitura no caso de terrenos municipais.

Notou-se que alguns problemas apontados pelos moradores coincidiram com os levantamentos das pesquisas, especialmente quanto à problemática dos resíduos, o que ratifica a necessidade de intervenções nessa área.

Com o fim da apresentação, partiu-se para a discussão conjunta de ações a serem tomadas. Foi destacada a importância de se despertar a coletividade dos moradores para que seja promovida uma mobilização com poder para buscar as transformações necessárias. Uma das propostas feitas para buscar essa coletividade foi a criação de um programa de educação ambiental para toda a população da região. Essa organização do coletivo poderia promover a execução de outra proposta apresentada, que foi o encaminhamento para o Ministério Público dos estudos realizados na área que evidenciavam a situação de fragilidade ambiental, pois tais informações deveriam ser aproveitadas para reivindicar junto ao poder público as intervenções necessárias, sendo colocado dito por eles que era de suma importância agir primeiramente sobre a questão da nascente e da contaminação que estava ocorrendo. 
Também foi posta em discussão a proposta de que as ações já realizadas na região do córrego São Rafael fossem aplicadas ao córrego Douradinho, como instituí-lo como Área de Especial Interesse Ambiental, o que promoveria maior visibilidade ao local.

Outra proposta foi realizar a divulgação de informações sobre a qualidade do sistema de abastecimento, esgoto e drenagem, uma vez que o SAAE realiza o monitoramento desses sistemas, pois um dos participantes apontou que existia grande precariedade de manutenção desses sistemas, inclusive com falhas nas bombas que regulam a cloração e fluoração na caixa d'água da região, situação que poderia levar ao surgimento de coliformes ferrosos nas tubulações.

Os problemas apontados com o plantio de mudas e poda de árvores voltaram à discussão nesse momento, tendo sido dada a sugestão de haver um planejamento adequado da arborização urbana que previna futuros danos, uma vez que foi apontado por um dos participantes que até os próprios moradores coletam mudas nas bordas dos fragmentos próximos e plantam esses indivíduos nas calçadas, e como essas espécies não são adequadas para isso, o sistema radicular acaba destruindo os pavimentos.

A figura 6 ilustra alguns dos problemas elencados ao longo das discussões.

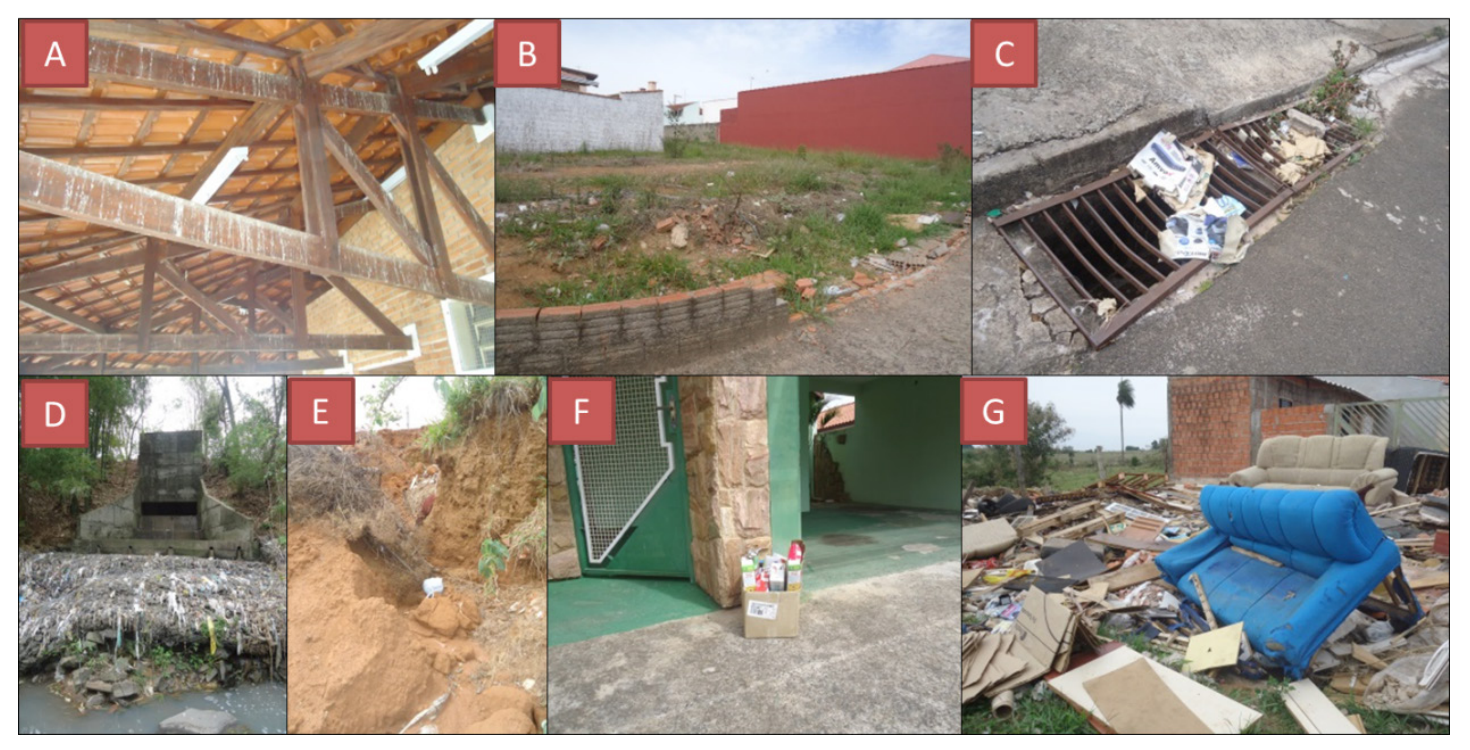

Figura 6: A- Quiosque da praça central abandonado e infestado por pombos; B- Terrenos baldios sem manutenção adequada; C- Bueiros obstruídos por resíduos; D- Ponto de escoamento da água pluvial do bairro sem manutenção adequada; E- Pontos de erosão; F- Problemas com a coleta seletiva; G- Pontos de acúmulo de entulho.

Foi proposta por um dos participantes a criação de um parque ecológico na região que integrasse as áreas naturais existentes com áreas municipais que se encontravam desocupadas, mas que poderiam ser adequadas para tal uso, conciliando o uso recreativo e educativo à conservação das nascentes e dos corpos hídricos, o que foi ao encontro de outra proposta que o grupo havia desenvolvido ao longo das pesquisas anteriores. Esse parque ecológico poderia seguir modelos já existentes no município, e assim foi sugerido o contato com outras associações e ONGs (como a ONG Veredas, atuante em outro conjunto de bairros do município de São (arlos/SP) que atuaram na criação dessas áreas para iniciar o estudo de viabilidade do projeto.

Durante esse momento da discussão, foi detectada certa dificuldade para se estabelecer um foco de ação, pois os participantes, mesmo quando questionados, não sabiam ao certo como priorizar as intervenções necessárias, o que foi mais prejudicado com a saída de alguns participantes, pois não poderiam mais continuar na discussão. Com isso, acabaram sendo colocadas propostas muito interessantes, mas não houve produtividade igual na construção dos meios para viabilizar tais propostas.

O resultado mais significativo dessa etapa foi a demanda por parte dos moradores por uma nova reunião para que a discussão pudesse continuar e para que fossem melhor embasadas as estratégias de ação, o que não estava previsto pela equipe e que levou à reestruturação do próprio projeto. Os participantes solicitaram que a equipe organizasse as informações apresentadas e as discussões realizadas em um documento para que fosse avaliado na reunião subsequente, a fim de submetê-lo ao Ministério Público ou outro órgão futuramente. 


\section{Segundo Encontro}

O segundo encontro (Figura 6), realizado no dia 09 de novembro de 2013, seguiu a mesma estrutura do encontro anterior, (do primeiro encontro,), porém era focado na discussão de estratégias para buscar soluções para os problemas, de modo que houve somente um rápido diagnóstico dos problemas percebidos pela população, os quais coincidiram com os pontos levantados na reunião anterior, e uma apresentação rápida das pesquisas. Nesse encontro, foi possível contar com a participação de outros moradores que não estavam presentes na primeira reunião, dentre eles o Vereador Aparecido Donizetti Penha, que é morador e atua na região.

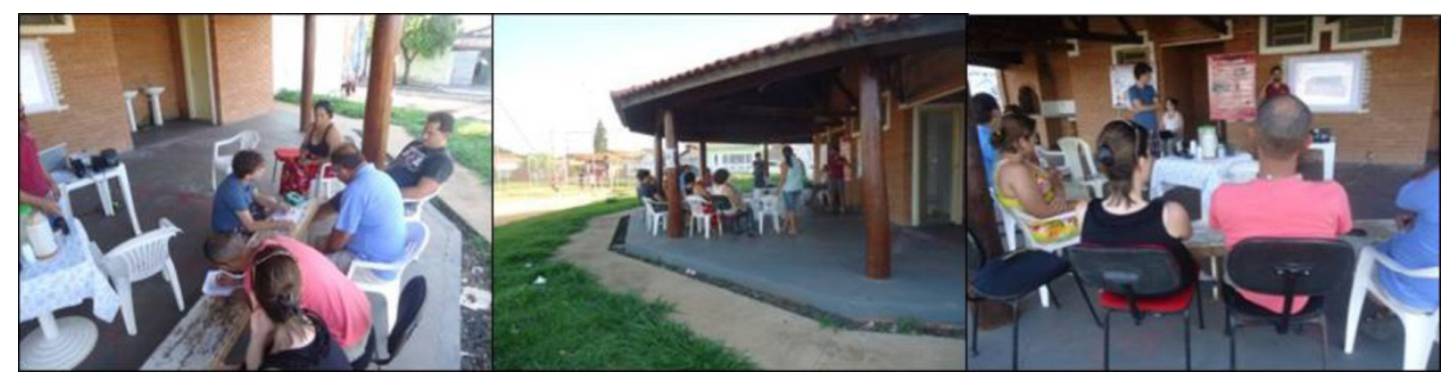

Figura 7 - Segundo Encontro seguindo a mesma sequência de momentos do anterior.

Grande parte da discussão realizada (Apêndice) ateve-se à dificuldade de se pensar em um sistema de gestão de resíduos que fosse adequado ao contexto local. A equipe apresentou aos participantes a proposta de um ecoponto para a região, projeto que houvera sido planejado pelo poder municipal havia anos passados para o bairro Douradinho, porém, abandonado. A recepção da ideia não foi muito boa, pois alguns participantes se mostraram resistentes à proposta, considerando-a inviável. Essa mesma reação foi constatada em alguns participantes da primeira reunião, e acabou não deixando de ser infundada, devido às más condições nas quais se encontravam os ecopontos na cidade, naquele momento.

Houve a explanação de que a proposta do ecoponto deveria ser a de um sistema bem organizado para a destinação adequada de materiais recicláveis e resíduos de construção civil (RCC), e que sua instalação não levasse à degradação da paisagem local. Entretanto, a atual situação da gestão do sistema de ecopontos no município de São Carlos não tem sido eficiente, e o encerramento do aterro que recebia o RCC coletado dificulta ainda mais o gerenciamento dos resíduos, o que leva a uma necessidade de reorganização desse sistema para que seja proposto de maneira adequada, e que não se corroborem os preconceitos que a população possui sobre tal sistema.

Contrapondo a proposta do ecoponto, surgiram ideias dos participantes para a construção de um sistema de gerenciamento dos resíduos recicláveis. Uma das propostas foi a destinação de verba municipal para contratar trabalhadores que atuassem em um sistema descentralizado para gerir os resíduos da região. É uma proposta interessante, mas carece de maiores investigações quanto à sua viabilidade, dada a carência de verba existente. Pode-se pensar em estudar diferentes dimensões de abrangência desse sistema para conhecer aquela que apresente maior viabilidade, por exemplo. Porém não houve aprofundamento nessa questão durante a discussão.

A situação da associação de catadores COOPERVIDA, responsável até então pelo recolhimento do material reciclável, entrou na pauta em dado momento. Tal associação não chega a atender à região e, segundo relato dos moradores, quando Ihes foi solicitado o serviço de coleta na região, a mesma alegaram não disponibilizar de infraestrutura suficiente para expansão de sua área de atuação. Entretanto, um dos participantes relatou que realiza a separação de seus resíduos, aguarda que haja certo volume de material reciclável e então contata a associação para que eles recolham o material. O atendimento pela associação para toda a região não é considerado viável dentro do cenário de recolhimento porta a porta, porém uma alternativa seria a implantação de pontos de entrega voluntária (PEVs) nos bairros, em que os moradores levariam até locais específicos os seus resíduos, e então o recolhimento seria feito somente nesses pontos, o que pouparia grande parte do trabalho da associação e tornaria sua atuação mais viável.

Foi retomada a problemática dos catadores informais por parte de um dos participantes, que relatou que alguns catadores apresentam interesse apenas em um tipo específico de material, de modo que espalham o resíduo apresentado pelos moradores para coleta, retiram o que Ihes é interessante e deixam o restante nas vias, que acaba 
sendo levado para regiões mais baixas, como ocorre em frente à sua moradia, e por fim chega aos córregos. Outra problemática apontada foi que existem carroceiros na região que coletam os RCCs gerados, mas que os descartam irregularmente nos terrenos baldios e nas áreas de fundo dos bairros, contribuindo muito para a formação desses pontos de descarte irregular. Verificam-se dois conflitos importantes, que podem contribuir dentro de um sistema de gestão de resíduos se forem readequados. Tanto os catadores informais quanto os carroceiros já realizam o recolhimento de alguns materiais; seria interessante estudar sistemas em que eles pudessem ser inseridos, de modo que continuassem a realizar suas atividades, porém que a logística do sistema e a destinação final dos resíduos fossem adequadas e eficientes.

Outro ponto muito discutido durante a segunda reunião foi o encaminhamento dos estudos técnicos feitos na região, a partir das reivindicações da população, formalizados como um plano de ação para a entidade competente, como o Ministério Público (MP), de acordo com a sugestão dada na reunião anterior. O documento elaborado pela equipe foi apresentado e os participantes o consideraram adequado. A proposta inicial de encaminhá-lo ao MP foi mantida. A ideia seria trabalhar com o recolhimento de assinaturas de moradores nos bairros, ratificando as informações e reivindicações contidas no plano de ação, para então enviá-lo ao MP. Porém, com a participação do Vereador Penha, surgiram novas possibilidades. O vereador motivou-se a participar da discussão, uma vez que no município estava ocorrendo a revisão do Plano Diretor e do Plano de Saneamento. Viu a oportunidade de, por meio da reunião, ouvir a população e obter informações para acrescentar na discussão dessas revisões. Com isso, surgiu a proposta de encaminhar o plano de ação diretamente ao Vereador Penha, que, em seu papel, estaria representando a vontade dos moradores da região, o que dispensa a necessidade de recolhimento de assinaturas. Esse plano seria submetido como um requerimento ao plenário para ser votado e encaminhado à prefeitura para cobrar o cumprimento das obrigações ambientais. Além disso, serviria como um documento para ser colocado em discussão dentro da revisão dos planos, com a proposta de a região ser considerada de ação prioritária. Todos os presentes concordaram com a nova estratégia, e a equipe responsabilizou-se por finalizar o plano e enviá-lo ao vereador. Uma vez encaminhado o plano, ficou acordado que seria feito um acompanhamento, por parte dos moradores e da equipe do projeto, do que estava sendo discutido, e, caso não houvesse intervenção do poder público nos problemas relatados, haveria encaminhamento direto ao MP.

Por sua vez, esse acompanhamento dependia de uma organização, e em vários momentos da reunião foi tocada a questão da necessidade de organização social e popular para assumir compromissos e buscar as soluções necessárias dos problemas discutidos, como o estudo de alternativas para a gestão dos resíduos. Alguns participantes, como o vereador, alertaram ser fundamental a participação e a representação em audiências públicas, por exemplo, para que os anseios da população fossem ouvidos nos momentos decisórios. Surgiu novamente a importância da coletividade, no sentido de ocupar os espaços públicos e se organizar na busca de qualificação e melhorias desses espaços, por meio de cobrança dirigida à prefeitura, bem como na busca de que seja feito um uso adequado de outras áreas ociosas. Com base nessa atuação, seria possível buscar a redução das áreas ociosas, que é um dos maiores problemas da região, pois essas áreas estão ligadas diretamente ao acúmulo de resíduos em locais inadequados, ocasionando a degradação do ambiente e a disseminação de vetores de doenças. Apontou-se também que os bairros que apresentam uma organização local, como associações de moradores, conseguem melhor representação perante a prefeitura e intervenções locais. A partir de todas essas observações ao longo das discussões, foi proposta a reorganização da associação de moradores do bairro, que se encontrava desativada. Isso partiu dos próprios participantes, sendo que surgiram voluntários para ocupar os cargos da associação, inclusive a presidência. Houve a consciência coletiva de que por meio da associação organizada as discussões poderiam continuar e amadurecer na busca das soluções. Esse resultado não estava previsto, e foi considerado um dos maiores ganhos do projeto, pois permite a continuidade das discussões e promove o envolvimento da população com os problemas locais.

Ao final da reunião, surgiu a demanda de um novo encontro para discutir o processo de reconstrução da associação, que deverá se iniciar pela recuperação dos documentos já existentes no cartório e, assim, dar entrada ao processo de criação de uma nova chapa e consolidação da associação. 


\section{DivUlgação e Continuidade}

A divulgação do trabalho foi feita por meio de diversas vertentes, como já citado na metodologia.

Para as reuniões, os cartazes (Figura 7) foram considerados necessários para aumentar a abrangência da divulgação, e um aspecto considerado significativo foi o de que a maioria dos comerciantes em cujo comércio foi afixado o cartaz perguntou sobre o projeto, apresentaram interesse em compreender de que se tratava e em divulgar para pessoas que visitassem o comércio. Alguns se comprometeram a comparecer na reunião, o que acabou não ocorrendo.

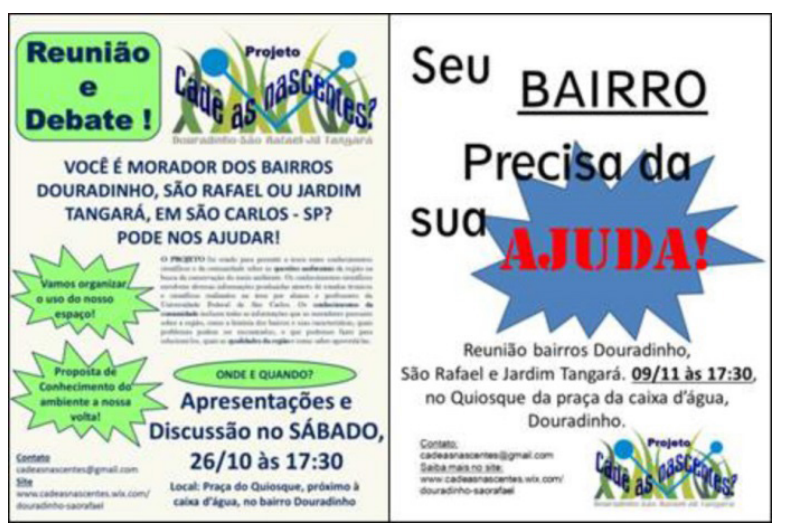

Figura 8 - Cartaz da primeira reunião (à esquerda) e da segunda reunião (à direita).

Foi citado por participantes da reunião que alguns deles viram os cartazes, porém não necessariamente esse foi o meio de divulgação a que tiveram acesso primeiramente. De forma geral o cartaz não é tão abrangente, porém é um esforço necessário, porque se ao menos um indivíduo que viu o cartaz compareceu, podemos considerar como resultado positivo. A divulgação segue a linha de buscar atingir o máximo de pessoas possível, então se considera que qualquer tipo de esforço que seja viável é válido, sendo que a divulgação nas escolas estabelece a mesma linha de pensamento que os cartazes. Não foi citado por nenhum participante o recebimento da filipeta, o que pode indicar que nenhum presente recebeu a informação da reunião por esse meio de comunicação.

O meio de comunicação considerado mais eficaz para a divulgação foi o carro de som, pois este passava por todas as ruas da região, e realmente quem estava em casa no momento acabava escutando a informação, como foi testado pela equipe do projeto. Além disso, alguns participantes da segunda reunião, para a qual foi utilizado esse meio de divulgação, citaram terem escutado o carro de som.
Quanto ao Facebook, este foi considerado não só um mecanismo de divulgação, mas também de continuidade do projeto. Além disso, essa rede social também favoreceu o encontro e a comunicação entre os próprios moradores, podendo vir a ser um espaço de troca, de denúncia e de mobilização social. Os números de abrangência apresentam resultados estimulantes: cerca de 392 pessoas visualizaram as informações postadas no perfil, ao total, sendo que 294 são moradores de São Carlos, dos quais não podemos garantir quantos são moradores dos bairros. Já pessoas que acompanham as publicações e recebem todas as informações postadas somam 46 pessoas, sendo 31 de São Carlos, 63\% mulheres e 37\% homens. Analisando tal grupo, pudemos concluir com absoluta certeza que ao menos 15 participantes são realmente moradores da região. Os números foram considerados satisfatórios para um início de divulgação, sendo necessário, para que se estabeleça o grupo como mecanismo de comunicação, uma divulgação mais intensa e um volume de postagens maior. Analisando-se os dados, percebe-se que os picos de novas adesões ao perfil do projeto aconteceram durante as postagens. Além disso, um dos resultados mais significativos foi o contato feito pelo Facebook com o Vereador Penha, que encontrou o projeto por meio do perfil e que se mostrou uma grande contribuição para a segunda reunião.

Por fim, outro meio de divulgação que se mostrou bastante relevante foi o site, principalmente do ponto de vista de continuidade e de carga de informações. O site, apesar de não possuir tamanha circulação de pessoas como as Redes Sociais, permite que se mantenha disponível um maior volume de informação, sendo que o site www. cadeasnascentes.wix.com/douradinho-saorafael (Figura 9) foi utilizado como um local em que pudessem ser mantidas, de forma didática e resumida, todas as informações concebidas sobre os bairros até o momento. Isso permite que pessoas que se interessem em se aprofundar de forma mais significativa no assunto ou precisem da informação para algum outro fim tenham um fácil acesso a este conteúdo, além de manter a divulgação das reuniões e fotos dos eventos realizados. No total o site recebeu, até o dia 11/12/2013, 99 acessos, o que foi considerado muito positivo, indicando que a informação está sendo realmente acessada. 


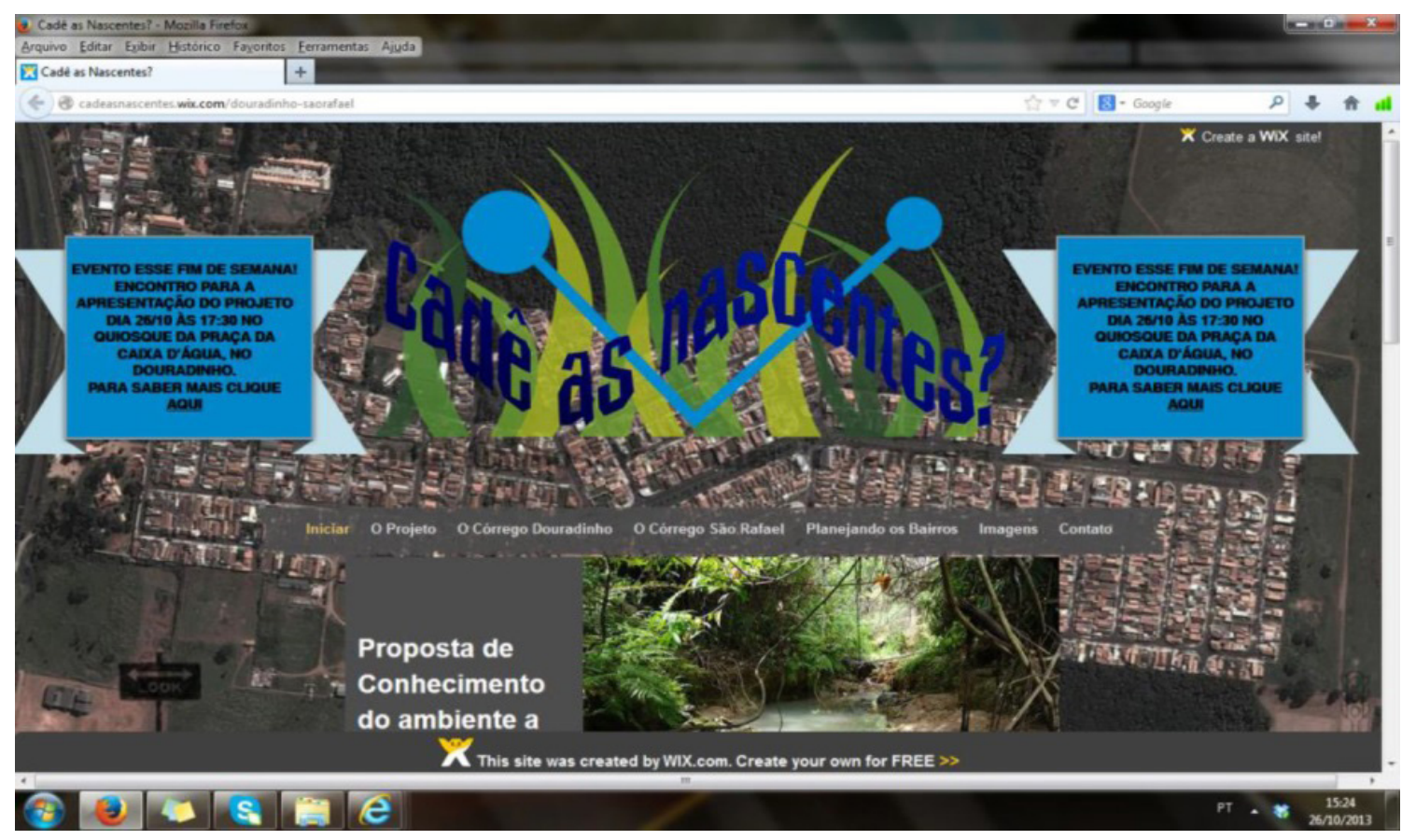

Figura 9 - Layout do site, divulgando as informações dos bairros e da reunião.

\section{CONCLUSÕES}

Existem algumas considerações a respeito da metodologia utilizada. A primeira é que uma das maiores dificuldades encontradas durante a realização do grupo focal é a administração dos indivíduos que tentam impor suas opiniões e visões e tendem a dominar o discurso, dificultando um diálogo aberto, principalmente com as pessoas mais tímidas. De acordo com a metodologia do grupo focal, o moderador não deve influir sobre a discussão para evitar isso. Porém, a proposta de trabalho dos grupos focais, que exige uma quantidade limitada de participantes, colabora para que essa dificuldade seja minimizada, pois a composição reduzida do grupo permite um ambiente mais íntimo, em que mesmo os mais tímidos expressam suas opiniões. Já os indivíduos que tentaram dominar o discurso foram administrados pelo moderador, que constantemente incentivava a apresentação de novas opiniões dos outros participantes.

A segunda consideração é a própria construção do diálogo entre as diferentes visões, local e científica. Devido à diversidade dos participantes proposta pela metodologia de grupo focal, os quais possuem, portanto, bases teóricas diferentes, é necessário que a equipe do projeto adapte o discurso, a fim de que a visão científica seja compreendida pelo grupo.)

De forma geral, conclui-se que o grupo focal é uma metodologia ideal para o estabelecimento de um espaço de discussão, uma vez que possibilita que os problemas ambientais sejam abordados e discutidos em grupo, resultando na própria construção coletiva do plano de ação. Isso ocorre, pois a metodologia permite que exista um espaço para todos contribuírem devido à administração do moderador e quantidade reduzida de participantes. Além disso, a metodologia inclui um relator que permite que todas as informações pertinentes à realização do trabalho não sejam perdidas ou que algumas opiniões não deixem de ser levadas em conta devido a alguma perda de informação, permitindo favorecendo que o moderador se concentre em apenas conduzir a discussão sem se preocupar em guardar todas as informações relevantes. Dessa forma, amplia-se a qualidade da discussão, facilitando o alcance dos objetivos do presente trabalho.

Por meio das informações descritas e dos resultados obtidos na realização deste trabalho, conclui-se que os objetivos propostos foram alcançados e que até mesmo alguns produtos inesperados ocorreram durante a realização do projeto. O plano de ação, produto do diálogo entre os saberes científicos e locais contendo as necessidades da população foi devidamente elaborado, com a aprovação dos participantes das reuniões. O número de participantes foi considerado suficiente para ratificar o plano em nome de 
todos os moradores. Houve ampla divulgação dos encontros realizados e compareceu quem pôde e teve interesse de contribuir para a elaboração do documento. O plano foi encaminhado para o poder público por meio de um vereador morador do local e será utilizado na discussão do plano diretor de São Carlos. Além disso, se as reivindicações não forem executadas, não se descarta a possibilidade de encaminhamento do relatório para o Ministério Público, sendo que a equipe do projeto, futuramente, junto com representantes da população, se manterá atenta aos avanços do plano.

Outro ponto é quanto ao incentivo à mobilização social, que foi um dos resultados do trabalho. Durante as reuniões, as pessoas manifestaram-se favoráveis à participação em uma organização para retomar a associação de moradores de bairro, inclusive uma delas voluntariou-se como candidata à presidência da associação, observando que parte dessas pessoas, apesar de moradoras antigas do bairro, nunca tinham antes participado dos eventos de mobilização da comunidade. O único entrave encontrado foi quanto à documentação da associação de moradores, que está atrasada e não está disponível para acesso, já que o último presidente que mantinha tais documentos não mora mais na região. É necessário que se entre com um processo de solicitação da documentação em cartório, o que está atualmente sendo providenciado. Dessa forma, pode-se dizer que este trabalho contribuiu para a retomada da associação de moradores e da mobilização social em geral.

Quanto à continuidade do diálogo entre conhecimentos, esta será proporcionada pela própria associação de moradores, quando estiver reaberta, mas também pela fundamentação teórica disponibilizada para a população por meio do website, que permite aos moradores acesso a conhecimento teórico e prático para melhoria das condições ambientais do bairro. Outro elemento importante de diálogo é aquele em que informações técnicas estão associadas a demandas locais na confecção do Plano de Ação que foi entregue para análise à Prefeitura Municipal de São Carlos. Para complementar a integração, outro espaço virtual que também está disponível para divulgação, troca de informações e planejamento do bairro é um perfil no Facebook, que também teve aceitação e divulgação satisfatórias, podendo ser um mecanismo muito útil para tais fins.

Por fim, os próprios participantes da comunidade, por meio das reuniões, puderam realmente contribuir e colocar em prática suas ideias e atitudes, no que diz respeito à sua relação homem/meio ambiente, as quais foram complementadas pelas apresentações teóricas realizadas pela equipe do projeto.
A continuidade e fortalecimento das ações propostas serão possibilitados pelas parcerias estabelecidas, pela mobilização social iniciada e pelos meios de comunicação e bases teóricas disponibilizadas à comunidade. Observa-se, neste momento, a mesma perspectiva de crescimento citada por SOARES (2008) em seu trabalho também com a comunidade do Douradinho:

\begin{abstract}
Nossas ações se modificam conforme nosso entendimento de nossos problemas e nossa força de grupo. Aceitamos com mais sapiência as dificuldades inerentes a esse processo, a experiência nos fez isto. Estamos sempre à procura de parcerias que nos fortaleçam e neste sentido temos feito grandes progressos. A continuidade das ações é a principal consequência desse processo que está em plena atividade se fortalecendo cada vez mais.
\end{abstract}

Isso nos leva a acreditar em um recomeço de um ciclo de crescimento de mobilização social em torno de ações de conservação do ambiente natural ali presentes, a questão base deste trabalho, e permite vislumbrar uma nova conformação das variáveis constitutivas do território em prol da melhoria da qualidade ambiental. 


\section{Tabela - Síntese dos Principais Problemas e Reinvindicações Indicados pela População}

\begin{tabular}{|c|c|}
\hline Coletividade & Falta de conscientização. \\
\hline \multirow{4}{*}{$\begin{array}{l}\text { Gestão dos } \\
\text { Resíduos }\end{array}$} & Presença de entulhos e acúmulo de resíduos em terrenos baldios, gramados e finais de ruas. \\
\hline & Ausência de coleta seletiva formalizada e sujeira nas ruas devido à ação de catadores informais. \\
\hline & Carreamento de resíduos para as nascentes e sua dispersão ao longo dos córregos. \\
\hline & $\begin{array}{l}\text { Ausência de gradeamento nos dissipadores de energia ou mecanismos para a contenção de } \\
\text { resíduos. }\end{array}$ \\
\hline \multirow{3}{*}{$\begin{array}{c}\text { Equipamentos } \\
\text { Urbanos }\end{array}$} & Ausência de escolas que atendam à população em várias faixas etárias, como EMEls. \\
\hline & $\begin{array}{l}\text { Possibilidade de problemas com as árvores plantadas no canteiro central pelo uso de Salix } \\
\text { babylonica (salgueiro-chorão). }\end{array}$ \\
\hline & Falta de conservação e manutenção de locais públicos, causando risco às pessoas que os utilizam. \\
\hline \multirow{2}{*}{$\begin{array}{l}\text { Controle de } \\
\text { Zoonoses }\end{array}$} & Presença de animais perigosos provenientes de terrenos sem manutenção. \\
\hline & $\begin{array}{l}\text { Presença de vetores de doenças em locais públicos, como pombos no quiosque, e deterioração } \\
\text { desses locais. }\end{array}$ \\
\hline \multirow{6}{*}{ Planejamento } & $\begin{array}{l}\text { Possibilidade de soterramento da nascente do Córrego Douradinho e parte de seu curso inicial na } \\
\text { ocasião da construção do Parque Residencial Douradinho. }\end{array}$ \\
\hline & Isolamento do bairro e má organização de vias (apenas uma entrada e uma saída). \\
\hline & $\begin{array}{l}\text { Formação de processos erosivos nas áreas de nascentes pela ação da drenagem pluvial mal } \\
\text { planejada. }\end{array}$ \\
\hline & $\begin{array}{l}\text { Contaminação nos mananciais com a água de drenagem que contém resíduos sólidos, químicos e } \\
\text { orgânicos carreados ao longo dos bairros. }\end{array}$ \\
\hline & Dificuldade de realização de podas de árvores que causam danos à rede de energia \\
\hline & $\begin{array}{l}\text { Alta incidência de áreas ociosas, tanto públicas quanto privadas, que podem ser aproveitadas para } \\
\text { criação de mais espaços públicos e áreas verdes. }\end{array}$ \\
\hline
\end{tabular}

\section{Principais Reivindicações da População}

Intervenção imediata, quanto à problemática das nascentes e dos córregos, para proteger esses mananciais, em especial da contaminação.

Buscar para o córrego Douradinho melhorias como as aplicadas ao córrego São Rafael, tal como a instituição de sua região como Área de Especial Interesse Ambiental.

Monitoramento do sistema de drenagem e análise de sua água pelo SAAE e disponibilidade dos dados ao público.

Realização do planejamento do plantio das árvores com as espécies adequadas e poda feita pela prefeitura Instituição de um plano de manejo da arborização urbana.

Exploração do potencial turístico e promoção da conservação por meio da criação de parques públicos e educação ambiental.

Criação de mais áreas públicas de lazer e promoção de saúde nos bairros, aproveitando o potencial de menor circulação de carros.

Construção de sistemas de gradeamento nos dissipadores de energia para conter os resíduos e realizar sua manutenção.

Realização de investigações na rede de drenagem e esgotos para verificar a existência de ligações cruzadas.

Realização de estudos geológicos detalhados na região onde houve soterramento dos mananciais e construção de edificações para inferir sobre os riscos que esta área apresenta.

Realização de um diagnóstico dos resíduos gerados na região. 


\section{REFERÊNCIAS}

ALMEIDA, R. Levantamento Histórico e Ocupação urbana da Unidade de Estudo. In: SCHIEL, D. et al. O estudo das bacias hidrográficas: uma estratégia para educação ambiental. São Carlos: Rima, p.37-42, 2002;

CARVALHO, I. C. M. e GRUM, M. Hermenêutica e Educação Ambiental. In.: JÚNIOR, L. A. (org.) Encontros e caminhos: formação de educadoras(es) ambientais e coletivos educadores / Ministério do Meio Ambiente. Diretoria de Educação Ambiental. Brasília, p. 175-187, 2005;

CONSELHO NACIONAL DE MEIO AMBIENTE - CONAMA. Resolução n³57 de 17 de março de 2005. Ministério do Meio Ambiente;

FAUSTINO, A. S.; GUERRA-TÃO, N.; NUNES, M. R. S.; SOARES, R. G. S. e MOSCHINI, L. E. Caracterização ambiental do entorno das nascentes dos córregos Douradinho e São Rafael inseridos em núcleo urbano no município de São Carlos - SP. In: I JORNADA DE GESTÃO E ANÁLISE AMBIENTAL, 2012, São Carlos, SP. Anais... São Carlos: UFSCar, 2012;

FELIPPE, M. F. e JUNIOR, A. P. M. Consequências da ocupação urbana na dinâmica das nascentes em Belo Horizonte - MG. UFMG - Instituto de Geociências: Belo Horizonte, 2009;

FERRARA, L. Olhar periférico: linguagem, percepção ambiental. 2 ed. São Paulo: Editora da USP, 1999;

FLORIANI, D. Diálogo de Saberes: uma perspectiva socioambiental. In.: JÚNIOR, L. A. (org) Encontros e caminhos: formação de educadoras(es) ambientais e coletivos educadores. Volume 2. / Ministério do Meio Ambiente. Departamento de Educação Ambiental. Brasília, p. 105116, 2007;

GOOGLE EARTH, Imagens de satélite GeoEYE da região de São Carlos - SP: passagens de 2004, 2005 e 2011. Escala 1:100. Composição RGB 1, 2 e 3;

GOMES, E.S. e BARBOSA, E.F. A Técnica de Grupos Focais para Obtenção de Dados Qualitativos. Instituto de Pesquisa e Inovações Educacionais - Educativa, 7 pág. Fev. 1999. Acesso em 15 de setembro de 2013, disponível em: http://www.tecnologiadeprojetos.com.
br/banco_objetos/\%7B9FEA090E-98E9-49D2-A6386D3922787D19\%7D_Tecnica\%20de\%20Grupos\%20 Focais\%20pdf.pdf

GUIMARÃES, M. Intervenção educacional: do "de grão em grão a galinha enche o papo" ao "tudo junto ao mesmo tempo agora". In.: JÚNIOR, L. A. (org.) Encontros e caminhos: formação de educadoras(es) ambientais e coletivos educadores/ Ministério do Meio Ambiente. Diretoria de Educação Ambiental. Brasília, 2005;

MELAZO, G. C. Percepção ambiental e educação ambiental: uma reflexão sobre as relações interpessoais e ambientais no espaço urbano. Olhares \& Trilhas, Uberlândia. Ano VI, n. 6, p. 45-51, 2005

SÃO CARLOS. Lei № 13.691 de 25 de novembro de 2005. Plano Diretor do Município de São Carlos. Capítulo III, Seção III, p 47, 2005;

SÃO CARLOS. Lei N¹3.944, de 12 de dezembro de 2006. Dispõe sobre a criação das Áreas de Proteção e Recuperação dos Mananciais do Município - APREM e dá outras providências;

SOARES, R. G. S. Proposta de intervenção em educação ambiental no bairro: Parque Residencial Douradinho. Monografia - Curso de Especialização em Educação Ambiental - Universidade Federal de São Carlos: São Carlos, 2008;

TUCCI, C. E. M. Gestão de águas pluviais urbanas. Ministério das Cidades: UNESCO, 2005.

Recebido em: 15/03/2014

Aceito em: 16/09/2014 